\title{
Sulfur and strontium isotopic study of epithermal mineralization: A case study from the SE Afar Rift, Djibouti
}

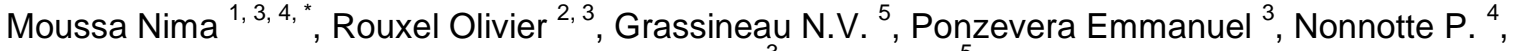 \\ Fouquet Yves ${ }^{3}$, Le Gall B. ${ }^{5}$
}

${ }^{1}$ IST, Centre d'Etude et de Recherche de Djibouti, BP 486, Djibouti

${ }^{2}$ University of Hawaii, Honolulu, HI 96822, USA

3 IFREMER, Centre de Brest, BP 70-29280, Plouzané, France

4 UMR 6538 Domaines Océaniques, UBO-IUEM, Place Copernic, 29280 Plouzané, France

${ }^{5}$ Department of Earth Sciences, Royal Holloway University of London, Egham, Surrey TW20 0EX, UK

* Corresponding author : Nima Moussa, email address : nmoussae@gmail.com

\begin{abstract}
:
Epithermal mineralization was recently described in synrift volcanic rocks from the SE Afar Rift in Djibouti. To infer fluid sources in this system, coupled sulfur and strontium isotopic analyses were performed on mineralized samples from hydrothermal veins and stockwork zones. Mineralization includes gypsum and chalcedony, and/or quartz \pm carbonate containing gold and sulfides. Sulfur isotopic compositions of sulfides and sulfates were determined using Multicollector-Inductively Coupled Plasma Mass Spectrometer (MC ICPMS); Laser Ablation MC ICPMS; and Continuous Flow Elemental Analyzer-Isotope Ratio Mass Spectrometry while strontium isotopes were determined by Thermal Ionisation Mass Spectrometry (TIMS) methods. Sulfur isotopic composition of sulfides (mainly pyrite) varies from -9.2 to $+6.6 \%$. These values are classically reported for hydrothermal sulfides resulting from the mixing of variable $S$ sources such as seawater sulfate and magmatic source. In addition, individual pyrite grains within the same sample show both positive and negative $\delta 34 S$ values suggesting multi-phase mineralization processes. Coupled sulfur and strontium isotopic compositions of seven sulfate samples hosted in (i) gypsum mound, (ii) evaporites, (iii) stockwork veins in sediments or in volcanic rocks were also investigated to characterize the sources of $\mathrm{Sr}$ and $\mathrm{S}$. The $\delta 34 \mathrm{~S}$ values of the sulfate ranged from -0.8 to $+14.3 \%$ while the $87 \mathrm{Sr} / 86 \mathrm{Sr}$ ranged from 0.70389 to 0.70639 consistent with variable mixing ratios of $\mathrm{Sr}$ and $\mathrm{S}$ derived from volcanic sources and seawater-derived sulfate. This study shows that, although precious-metal deposition is related to low-sulfidation epithermal environment, both acidic fluid of magmatic and saline origins contributed to the hydrothermal system in the SE Afar Rift.
\end{abstract}




\section{Graphical abstract}

Schematic representation of the model proposed. The numbers correspond to (1) Da'asbiyo2, Ali Addé, Hes Daba, Arta, Asa Leyta and Babba Alou; (2) Arta Plage, Babba Alou and Asa Leyta and (3) Lake Asal.

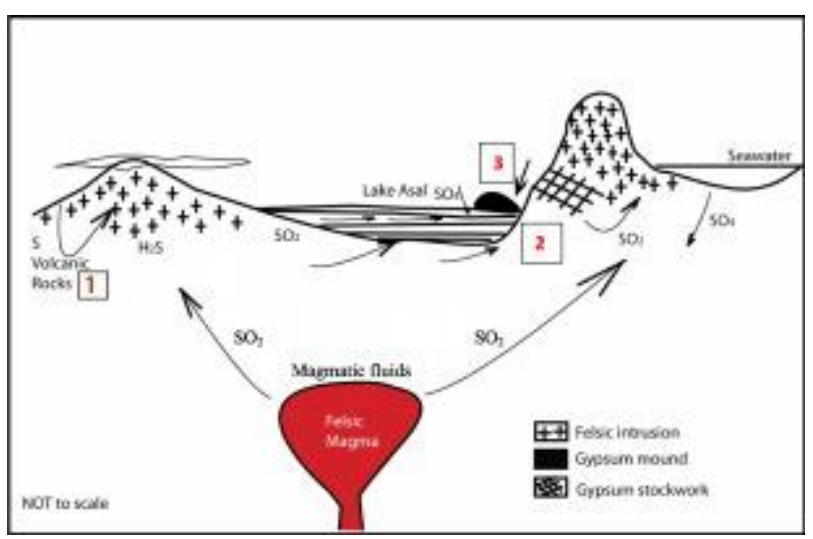

\section{Highlights}

Sulfur and strontium isotopic compositions of sulfides and sulfates of hydrothermal veins from the SE Afar Rift (Djibouti). Sulfur isotopic compositions of sulfides (mainly pyrite) vary from -9.2 to $+6.6 \%$. - Strontium compositions of mineralized veins fall between 0.7039 and 0.7079 . The $\delta^{34} S$ values of the sulfate (gypsum) range from -0.8 to $+14.3 \%$. The ${ }^{87} \mathrm{Sr} /{ }^{86} \mathrm{Sr}$ values of the sulfate fall in the range of 0.70389 to 0.70639 . Magmatic and saline fluids contributed to the hydrothermal system in the SE Afar Rift.

Keywords : Hydrothermal system, Sulfur isotopes, Strontium isotopes, SE afar rift, Epithermal 


\section{Introduction}

Epithermal deposits are important economic sources of $\mathrm{Au}$ and $\mathrm{Ag}$ in the world (White and Hedenquist1990; Hedenquist et al. 2000; Simmons et al. 2005). Epithermal deposits form in the shallow parts of high-temperature magmatic-hydrothermal systems (Simmons et al., 2000, 2005) and are generally grouped into high, intermediate and low sulfidation types based on mineral assemblages and their sulfidation states (e.g., Hedenquist et al. 2000; Sillitoe and Hedenquist 2003; Einaudi et al. 2003). There has been considerable debate on the origin of hydrothermal fluids leading to the formation of both high and low sulfidation epithermal deposits. Previous studies identified the importance of magmatic fluids while others argued that epithermal deposits form through the circulation of meteoric (sub-surface) fluids, without a direct relationship to a magmatic source (Henley and Ellis, 1983; Hayba et al., 1985; Simmons et al., 2005). High-sulfidation deposits are considered to form by magmatic fluids (Arribas, 1995) while low sulfidation deposits principally involve meteoric fluids with still significant contribution of magmatic fluids (Simmons, 1995).

Recent field investigations in the SE Afar rift (Djibouti) aimed at addressing the importance of hydrothermal fluids in rift-related volcanic complexes and their relation to the formation of epithermal deposits (Fig. 1) (Moussa et al., 2012). This region has been widely investigated since 1970 as it represents an active geological laboratory to investigate tectono-magmatic rift systems (Stieljes et al., 1973; Barberi et al., 1975; Le Gall et al., 2010; Pinzutti et al., 2013). The most active area is the Asal Rift which has been recognized as a subaerial analogue of slow-spreading ridges where active tectonics and volcanism can be directly observed. Based on geochemical and field studies, several types of hydrothermal ore deposits were identified in the Djibouti rift system (Moussa et al. 2012). The high abundance of gold in the base metal deposits from Hes Daba and Asa Leyta located nearby the Asal Rift (Fig. 1) provide an ideal analogue, of larger epithermal systems. In this paper, we aim to assess the origin and mixing relationships of the ore fluids in eight different sites from the Asal Rift. We applied coupled sulfur and strontium isotope studies of mineralized 
veins in the deposits to quantify the sources and interactions of the ore fluids with the source rocks and marine sulfate deposits.

Sulfur isotopic compositions have been widely used to investigate sulfide and sulfate deposition processes, and as tracers of sulfur sources (e.g. volcanic rocks, magmatic volatiles and seawater). Sulfur isotopic compositions of sulfides of epithermal deposits generally yield $\delta^{34} \mathrm{~S}$ values ranging from -15 to $5 \%$ depending on their geological settings: (i) -6 and $+5 \%$ for low-sulfidation with most values close to $0 \%$ (Ohmoto and Rye, 1979; Field and Fifarek, 1985); (ii) -15 to $+8 \%$ o for alkalic epithermal deposits (Richards, 1995) and (iii) -10 to $+8 \%$ for high-sulfidation deposits (Arribas, 1995). Heaviest $\delta^{34} \mathrm{~S}$ values are considered to represent a major contribution of seawaterderived sulfate, while negative $\delta^{34} \mathrm{~S}$ values are best explained by magmatic fluid contribution. In modern seawater, sulfur is found in an oxidized form as sulfate with an homogeneous $\delta^{34} \mathrm{~S}$ composition of $21 \pm 0.2 \%$ (Rees et al., 1978), although this value is known to have varied from 10 to 30 \%o during the Phanerozoic (e.g. Claypool et al., 1980; Paytan et al., 1998). Magmatic rocks derived from the upper mantle have sulfur isotopic composition similar to that of meteorites $\left(\delta^{34} \mathrm{~S} \approx\right.$ $0 \pm 2 \%$ ) (Thode et al., 1961; Sakai et al., 1984), although recent data have pointed to significant heterogeneity of $\delta^{34} \mathrm{~S}$ values in the mantle (Labidi et al., 2013). Sedimentary sulfides have a wide range of $\delta^{34} \mathrm{~S}$ values (-70 to $+70 \%$ ) (Claypool et al., 1980; Shen et al., 2000; Canfield, 2001) reflecting large $\mathrm{S}$ isotope fractionation during microbial sulfate reduction and diagenetic processes. Although sedimentary (i.e. biogenic) contribution may in theory explain the occurrence of isotopically light $\mathrm{S}$ isotope signatures in epithermal deposits, the abiotic disproportionation of magmatic $\mathrm{SO}_{2}$ is considered to be the main mechanism producing sulfide (i.e. $\mathrm{H}_{2} \mathrm{~S}$ ) with negative $\delta^{34} \mathrm{~S}$ values.

Sulfur isotopic compositions have been also intensely investigated in seafloor hydrothermal systems located along fast and slow spreading ridges and in back-arc settings (e.g. Arnold et al., 1981; Alt et al., 1989; Shanks et al., 1995; Rouxel et al., 2004, Ono et al., 2007). These studies demonstrated that along mid-oceanic ridges, seafloor hydrothermal sulfides (active and inactive deposits) commonly 
yield $\delta^{34} \mathrm{~S}$ values from -1 to $+11 \%$. These values are explained by a major contribution of sulfur derived from the basalt and a smaller contribution from inorganically reduced seawater sulfate (Arnold et al., 1981; Shanks et al., 1995). Using multiple S-isotope ratios $\left({ }^{32} \mathrm{~S},{ }^{33} \mathrm{~S}\right.$ and ${ }^{34} \mathrm{~S}$ ), Ono et al. (2007) have also addressed the importance of partial $\mathrm{H}_{2} \mathrm{~S}_{-} \mathrm{SO}_{4}^{2-}$ isotope exchange in hydrothermal chimney environments. The $\delta^{34} \mathrm{~S}$ values for hydrothermal sulfides from sedimented mid-ocean ridges spread between -4 to $+17 \%$ (Escanaba Trough, Guaymas and Middle Valley). In these environments, it has been suggested that sulfur has multiple sources including basalts, inorganically reduced seawater sulfate and isotopically light biogenic sulfur remobilized from marine sediments (e.g. Goldhaber and Kaplan, 1974; Zierenberg 1994; Herzig et al., 1998b). In back-arc environments, hydrothermal deposits have $\delta^{34} \mathrm{~S}$ values ranging from -8 to $+16 \%$ (Herzig et al., 1998a; Gemmell et al., 2004; Kim et al., 2004, 2006). The light $\delta^{34} \mathrm{~S}$ values in sulfides have been commonly explained by the isotope fractionation effects which accompany the disproportionation of magmatic $\mathrm{SO}_{2}$ into $\mathrm{H}_{2} \mathrm{~S}$ and $\mathrm{H}_{2} \mathrm{SO}_{4}$ (Herzig et al., 1998a; Gemmell et al., 1999; Reeves et al., 2010).

Strontium isotopes have been also used to infer the source of ore fluids in different types of hydrothermal systems including epithermal systems and active or fossil seafloor hydrothermal systems (Elderfield and Greaves, 1981; Richard, 1995; Arribas et al., 1995; Arribas, 1995; Polliand and Moritz, 1999; Rainbow et al., 2005). Unlike S isotopes, Sr isotopes reflect predominantly the signatures of the source rocks from which $\mathrm{Sr}$ has been leached. Combining $\mathrm{Sr}$ and $\mathrm{S}$ isotope analyses of sulfate may therefore provide complementary constraints on the source of mineralization fluids and potential contributions of marine waters or evaporites (Shikazono et al., 1983; Mills et al., 1998; Teagle et al., 1998; Mills and Tivey, 1999; Paytan et al., 2002; Alt and Teagle, 2003; Kim et al., 2004; Craddock et al., 2008;). Here we aim at using a similar approach by applying coupled S and Sr isotope composition of sulfate mineral assemblages from the Afar Rift as indicators of fluid-wall rock interaction and mineralization fluid sources. 


\section{Geological setting}

The Afar rift system is located at the triple junction between the onshore prolongation of the Red Sea and Gulf of Aden ridges, and the Main Ethiopian continental rift (Fig. 1). The Afar lithosphere recorded long-lived tectonic and magmatic accretionary processes in relation to the initial emplacement of the Afar mantle plume $30 \mathrm{Ma}$ ago, and subsequent far-field extension (Barberi et al., 1975; Audinet al., 2004). This resulted in incipient continental rupturing along discrete tectonovolcanic ranges, one of them occurring in SE Afar, Djibouti, along the Tadjoura-Ghoubbet-Asal axis (Manighetti et al., 1997; Pinzutti et al., 2013).

The most complete section of the Afar synrift volcanic succession is exposed in Djibouti, including the 21-28 Ma-old Ali Sabieh mafic series, the extensively distributed basalts of the 1-3 Ma-old Stratoid-Gulf series and the more localized and younger Asal volcanics (Gasse et al., 1986; Le Gall et al., 2010). Hydrothermal processes are known to have occurred over the 28 Ma-long Afar rift history in Djibouti (Moussa et al., 2012). The area considered for this study has been previously described in terms of geological setting and hydrothermal mineralization in Moussa et al. (2012). It consists of several sites: Ali Addé, Da'asbiyo2, Arta Plage, Arta, Babba Alou, Hes Daba, Asa Leyta and Lake Asal (Fig. 1)

The Ali Addé and Da'asbiyo2 sites are hosted by the 11-15 Ma-old felsic series that forms the outer rim of the Ali Sabieh antiform, South Djibouti (Barberi et al., 1975; Gadalia, 1980; Le Gall et al., 2010). The latter consists of rhyolites, ignimbrites and minor basaltic lava flows and the associated felsic feeder dykes (Gadalia 1980).

The Arta Plage site occurs on the southern coast of the Tadjoura Gulf where 4-9 Ma-old Dahla basalts, and younger felsic lavas and intrusions of the Ribta formation (4-3 Ma) build up a large N-S-elongated antiform, unconformably overlain by Stratoid (1-4 Ma) and Gulf (1-3 Ma) basalts (Robineau, 1979; Deniel et al., 1994; Daoud et al., 2011).

The Babba Alou, Hes Daba and Asa Leyta sites are hosted by the 1-3 Ma Stratoid trap-like volcanic series that covers about two-thirds of the Afar depression. Hydrothermal activity is related to felsic 
centers emplaced within the Stratoid mafic pile, such as the <2 Ma-old Babba Alou massif, near the Lake Abhé (Gasse and Street 1978), and within intermediate Stratoid basalts, such as the Hes Daba and Asa Leyta sites, between the Gaggadé and the Asal faulted depressions.

The Lake Asal site occurs in exceptional geological, topographical and hydrogeological settings. It is located $155 \mathrm{~m}$ below sea level and $\sim 12 \mathrm{~km}$ away from the Red Sea, along the tectonically active floor of the Asal rift (Gasse and Fontes 1989). The Asal rift is the locus of still active hot springs forming carbonate chimneys and fumaroles associated with young $(<1 \mathrm{Ma})$ volcanism (Stieljes, 1973; de Chabalier and Avouac, 1994) (Fig. 2- A). The thermal spring and geothermal waters recovered from wells drilled at depths ranging from 1150 to $2000 \mathrm{~m}$ in the southern flank of the rift have been already studied in terms of geochemical and isotopic $(\mathrm{Sr}, \mathrm{C}, \mathrm{O})$ compositions (Bosch et al., 1977; Fontes et al., 1979; Fouillac et al., 1983; Sanjuan et al., 1990). These previous studies concluded that the hydrothermal fluids result from (i) basalt-seawater interaction, associated with high rates of evaporation in response to intense aridity and (ii) mixing between deep geothermal water and seawater or Lake Asal water. The Lake Asal is one of the few modern examples of marine-fed rift basin that is actively accumulating evaporites (Warren, 1997). Gypsum precipitation dominates in the southeastern part of the lake depression whereas the older layered and mounded gypsum beds crop out around the lake edge, as high as $55 \mathrm{~m}$ above the present lake level (Stieljes, 1973).

\section{Methodology}

\subsection{Sample preparation}

Prior to sample preparation for $\mathrm{S}$ and $\mathrm{Sr}$ isotope analyses, detailed mineralogical studies of hand specimen from the eight different sites were performed using reflected light microscopy at magnification up to 1000 in dry air and oil. Additional studies were performed involving X-Ray diffraction analysis to determine major minerals in gangue and alteration zones. 
Sulfur isotope analyses $\left(\delta^{34} S\right)$ were performed by EA-IRMS (Elemental Analyzer Ion Ratio Mass Spectrometer) and MC-ICPMS (Multicollector Inductively Coupled Plasma Mass Spectrometer) as described below. Sulfur isotope compositions of sulfide and sulfate minerals were analyzed at the Stable Isotopes Laboratory, Royal Holloway University of London by EA-IRMS VG/Fisons/Micromass "Isochrom-EA" system. This instrument consists of an elemental analyzer (EA1500 series 2) on line to an Optima mass spectrometer. The analytical procedure followed the method described in Grassineau (2006). Sulfide mineral separates were prepared by hand picking under a binocular microscope. Samples were weighed using a microbalance and crimped in tin capsules. The analyses were done by combustion of the samples and oxidation of the sulfur released to $\mathrm{SO}_{2}$ (Grassineau et al., 2000, 2001a). Sulfur isotope compositions of sulfides of mineralized veins were also analyzed by MC-ICPMS Thermo Scientific Neptune at the PSO (Pôle Spectrométrie Océan, Brest, France) following the analytical method described in Craddock and Bach (2010) and Craddock et al. (2008). For sulfur isotope analysis of pyrite, nineteen samples were crushed in a small agate mortar and $1 \mathrm{~g}$ of sample was weighed into a $15 \mathrm{ml}$ PTFE (polytetrafluoroethylene) digestion vessel. Samples were first reacted for 1 hour with $10 \mathrm{ml}$ of $0.2 \mathrm{M} \mathrm{HCl}$ acid in ultrasonic bath in order to dissolve carbonate and anhydrite. After centrifugation for $10 \mathrm{~min}$ at $3000 \mathrm{rpm}$ and discarding the surnageant, $2 \mathrm{ml}$ of distilled water were added to the residue and further centrifugated. The residue was dissolved in $5 \mathrm{ml}$ of $13.8 \mathrm{M} \mathrm{HNO}_{3}$ by heating at $100^{\circ} \mathrm{C}$ for at least 5 days and then evaporated to dryness. This step allows a complete digestion of pyrite and oxidation of sulfur to sulfate while leaving quartz (and other silicates) as a residue. The residues were then dissolved in $5 \mathrm{ml}$ of $0.28 \mathrm{M} \mathrm{HNO}_{3}$ and the solution was purified through cationic exchange chromatographic column. The column was filled with $2.5 \mathrm{ml}$ of AG50 X8 resin (Biorad) and washed with $20 \mathrm{ml}$ of $\mathrm{H}_{2} \mathrm{O}$. After loading $5 \mathrm{ml}$ of sample solution, the column was then washed with $15 \mathrm{ml}$ of $0.28 \mathrm{M} \mathrm{HNO}_{3}$ to obtain the final solution. Analyses of sulfur isotopes were reported as standard $\delta^{34} \mathrm{~S}$ notation relative to Vienna Canyon Diablo Troilite (V-CDT) using a set of calibrated internal standards and IAEA standards, as reported in Craddock et al. (2008). The reproducibility for 
measurements of sulfide and sulfate samples was $0.16 \%(2 \sigma)$ based on multiple analyses of both inhouse and international standards (IAEA-S1, IAEA-S-2, IAEA-S-3, AMR8-ZnS, FL-DR-03-Cpy, Laminita-FeS 2 , WARD'S-FES and NBS 123). We also applied a spatially-resolved method to measure $\mathrm{S}$ isotope ratios in pyrite ( 9 samples) using laser-ablation coupled to MC-ICPMS. Appropriate laser parameters for the determination of $\mathrm{S}$ isotopes were previously described by Craddock et al. (2008). The reproducibility of $\delta^{34} \mathrm{~S}$ measurements of sulfide samples was $0.25 \%$ $(2 \sigma)$ based on multiple analyses of our internal pyrite standards (GAV-18) which has been calibrated with respect to international standards as described in Craddock et al. (2008).

Strontium isotope analyses of 25 samples from mineralized veins were performed by Thermal Ionisation Mass Spectrometer (TIMS) (Thermo Scientific Triton) at PSO. Chemical purification of $\mathrm{Sr}$ was performed using a two-stage chromatography procedure: (1) on cationic Dowex AG50 X8 columns, and (2) a purification of the Sr part on Sr Spec resin (Chu et al., 2006). Accuracy of the analyses of ${ }^{87} \mathrm{Sr} /{ }^{86} \mathrm{Sr}$ was checked against the international standard NBS-987 and we obtained an average value of 0.710258 with a reproducibility of $0.000010(2 \sigma, \mathrm{n}=11)$.

A total of eight gypsum-rich samples were also analyzed by MC-ICPMS for coupled sulfur and strontium isotopes. We used a leaching procedure to recover $\mathrm{S}$ and $\mathrm{Sr}$ from gypsum. About 100 mg of sample was first reacted with $10 \mathrm{ml}$ of diluted $\mathrm{HNO}_{3}(0.5 \mathrm{M})$ for several hours. The surnageant was then recovered after centrifugation, and purified for $\mathrm{S}$ and $\mathrm{Sr}$ isotope analyses following the methods described above.

\section{Results}

\subsection{Mineralogy}

In all sites, sulfide mineralization occurs in chalcedony \pm massive quartz and carbonate veins with adularia (Fig. 3). The Da'asbiyo2 site is characterized by goethite and pyrite in breccia veinlets. In the Ali Addé area, quartz constitutes the principal gangue mineral and early 
mineralization consists of chalcopyrite, pyrite, hessite, tetradymite, sphalerite, galena and hematite (Fig. 2-C). Adularia is disseminated in quartz veins. Secondary minerals consist of bornite, digenite, covellite, marcasite and goethite. Alteration minerals such as illite and chlorite are also present. In contrast to other sites, the veins from Arta site contain gold, electrum, pyrite, argentite, hematite, goethite associated with chalcedony (Fig. 2-D-F). Opaque minerals of the Hes Daba site are composed of both hypogene minerals (e.g. pyrite, chalcopyrite, sphalerite, galena, hessite, petzite, tetradymite, pyrrhotite, hematite and magnetite) and supergene minerals (bornite, digenite, covellite, chalcocite, native $\mathrm{Cu}$, native $\mathrm{Ag}$ and goethite). They occur in banded chalcedony \pm adularia veins or breccias (Fig. 2-G). Late carbonate veins of barren sulfides and gold are common. Pyrite predominantly occurs as fine grains (5 to 100 micrometers in size) scattered throughout the rocks. Pyrite can also fill cracks or occurs in breccias at Babba Alou site, nearby the margins of the felsic intrusion. Sulfate minerals (i.e. gypsum) are encountered in (i) a gypsum mound; (ii) evaporites, (iii) stockwork veins in sediments or in volcanic rocks.

At Arta Plage site, a mineral assemblage of aragonite, calcite, dolomite, ankerite, and quartz is observed in veins in the altered volcanic rocks together with a stockwork of gypsum (Fig. 2-H). In the Asa Leyta area, two stockworks of gypsum containing small amounts of anhydrite probably related to an ancient saline lake, were identified along the main extensional fault zone through both the felsic lavas and the lacustrine sediments (Fig. 2-B). XRD analyses show that most of the samples of this study consist of rather pure gypsum. The most common accessory mineral associated with gypsum is anhydrite occurring as traces.

\subsection{Sulfur and strontium isotope ratios of sulfides and hydrothermal veins}

Sulfur isotopic composition of pyrite as well as sulfur and strontium isotopic compositions of hydrothermal veins are reported for more than 40 samples. The results are reported in Tables 1 and 2 and Figure 3. The $\delta^{34} \mathrm{~S}$ values of pyrite from the Mablas rhyolitic series (i.e. Da'asbiyo2 and Ali Addé sites) are relatively heavy (1.5 to $5.9 \%$ ) and the ${ }^{87} \mathrm{Sr} /{ }^{86} \mathrm{Sr}$ ratios of mineralized veins from Ali 
Addé range from 0.7072 to 0.7079 . At Arta, sulfur isotopic compositions of sulfides (pyrite) show two types of distributions: (i) light $\delta^{34} \mathrm{~S}$ values down to $-2.1 \%$ and (ii) heavy $\delta^{34} \mathrm{~S}$ values (up to $6.6 \%$ ) while ${ }^{87} \mathrm{Sr} /{ }^{86} \mathrm{Sr}$ values of mineralized veins range from 0.7044 to 0.7065 . Sulfur isotopic composition of pyrite from Babba Alou show light $\delta^{34} \mathrm{~S}$ values from -2.8 to $-0.2 \%$. Unfortunately, strontium isotope ratios were not analyzed in the Babba Alou area. Sulfur isotope compositions from the Hes Daba site lie between -9.2 and $5.2 \%$ and ${ }^{87} \mathrm{Sr} /{ }^{86} \mathrm{Sr}$ of mineralized veins range from 0.7039 to 0.7057 . At Asa Leyta, $\delta^{34} \mathrm{~S}$ values of pyrite spread between -6.4 and $5.9 \%$ while ${ }^{87} \mathrm{Sr} /{ }^{86} \mathrm{Sr}$ values of veins range from 0.7039 to 0.7074 .

\subsection{Strontium and sulfur isotope ratios of gypsum}

Coupled S and Sr isotope ratios of gypsum from Asa Leyta and Arta Plage sites are reported in Table 1. As a whole, ${ }^{87} \mathrm{Sr} /{ }^{86} \mathrm{Sr}$ ratios of gypsum vary between 0.7039 and 0.7064 . At Asa Leyta ${ }^{87} \mathrm{Sr}{ }^{86} \mathrm{Sr}$ and $\delta^{34} \mathrm{~S}$ range from 0.7046 to 0.7058 and -0.8 to $3.5 \%$, respectively. At Babba Alou site, the $\delta^{34} \mathrm{~S}$ values of gypsum cluster between -1.5 and $-0.2 \%$. At Arta Plage,${ }^{87} \mathrm{Sr} /{ }^{86} \mathrm{Sr}$ range from 0.7039 to 0.7064 while $\delta^{34} \mathrm{~S}$ values of gypsum range from -0.8 to $16.3 \%$ (Fig.4). The $\delta^{34} \mathrm{~S}$ value of gypsum from Lake Asal yields the heaviest values at $21.3 \%$.

\section{Discussion}

\subsection{Magmatic origin of sulfur and the potential importance of fluid boiling}

Sulfur isotopic compositions of sulfides (i.e. pyrite) from Hes Daba, Arta, Asa Leyta and Babba Alou sites are systematically light, with the lowest $\delta^{34} \mathrm{~S}$ value of $-9.2 \%$ measured at Hes Daba. Such values are consistent with the range of $\delta^{34} \mathrm{~S}$ values reported for epithermal gold deposits (Field and Fifarek, 1985; Arribas 1995; Cooke et al., 2011) and suggest a magmatic contribution (Fig. 5). Cooke et al. (2011) reported similar $\delta^{34} \mathrm{~S}$ values (-6.9 to $0.8 \%$ ) for the high sulfidation Baguio 
deposits (Philippines), and interpreted the results as reflecting a significant magmatic source. Similar interpretation was also proposed for modern seafloor hydrothermal deposits in back-arc basins where $\delta^{34} \mathrm{~S}$ values as low as $-7.7 \%$ were reported for pyrite at Hine Hina site in the Lau Basin (Herzig et al., 1998a; Gemmel et al., 1999). Sulfur isotope composition of gypsum from Asa Leyta $\left(\delta^{34} \mathrm{~S}\right.$ from -0.8 to $3.5 \%$ ) and Babba Alou $\left(\delta^{34} \mathrm{~S}\right.$ from -1.5 to $-0.2 \%$ ) are also much lighter than typical seawater sulfate signature of $21 \%$. Such light $\delta^{34} \mathrm{~S}$ values for sulfate are comparable to $\delta^{34} \mathrm{~S}$ of acid-sulfate minerals (e.g. alunite) measured in back-arc seafloor hydrothermal systems (Herzig et al., 1998a). Alunite is considered to reflect a magmatic component as suggested for its occurrence in some subaerial epithermal systems (Aoki 1991; Herzig et al., 1997) and requires the presence of additional acids such as $\mathrm{H}_{2} \mathrm{SO}_{4}$ derived from volcanic $\mathrm{SO}_{2}$ in order to precipitate (Henley et al., 1980; Rye 2005). In general, the $\mathrm{H}_{2} \mathrm{~S}_{\mathrm{SO}}$ ratio of evolved magmatic fluids is a function of the oxidation state of the magma, temperature and pressure (e.g., Symonds et al., 1994) and isotopically light $\delta^{34} \mathrm{~S}$ values of both sulfides and sulfates result from the input of magmatic $\mathrm{SO}_{2}$ according to the following reaction (e.g., Holland, 1965; Drummond, 1981; Herzig et al., 1998a) :

$$
4 \mathrm{SO}_{2}+4 \mathrm{H}_{2} \mathrm{O}=\mathrm{H}_{2} \mathrm{~S}+3 \mathrm{H}_{2} \mathrm{SO}_{4}
$$

The disproportionation of $\mathrm{SO}_{2}$ into reduced and oxidized species is accompanied by an isotope effect which causes the sulfide to become enriched in ${ }^{32} \mathrm{~S}$ and the sulfate enriched in ${ }^{34} \mathrm{~S}$ relative to magmatic $\mathrm{SO}_{2}$ (Ohmoto and Rye, 1979). In the near surface, $\mathrm{H}_{2} \mathrm{SO}_{4}$ leads to the formation of characteristic acid-sulfate alteration assemblages with $\delta^{34} \mathrm{~S}>0 \%$, although typically lower than seawater sulfate. Such disproportionation reaction, however, is generally difficult to identify since the produced sulfide and sulfate mineral assemblages are rarely coexisting in single sample specimen considering the contrasted mobility and stability of $\mathrm{H}_{2} \mathrm{~S}$ and $\mathrm{H}_{2} \mathrm{SO}_{4}$. Likewise, this type of acid-sulfate alteration assemblage has not yet been observed in the Djibouti rift system, preventing us to firmly conclude about the presence of magmatic acidic fluids in the system.

Further constraints on $\mathrm{S}$ isotope fractionation processes are provided by in situ $\delta^{34} \mathrm{~S}$ analyses (LA-MC-ICPMS) that show small-scale variations between individual pyrite crystals from Hes 
Daba, Arta, Asa Leyta and Babba Alou (Table 1). These variations suggest dynamic changes of $\mathrm{H}_{2} \mathrm{~S}_{\mathrm{SO}}$ ratios in the fluid source and/or variable mixing ratios between magmatic $\mathrm{H}_{2} \mathrm{~S}$ and $\mathrm{H}_{2} \mathrm{~S}$ derived from fluid-rock interactions and reduction of seawater sulfate. Previous studies proposed that boiling process in hydrothermal system involves a preferential loss of $\mathrm{H}_{2}$ and $\mathrm{H}_{2} \mathrm{~S}$ into the vapor phase, thereby causing an increase in the oxidation state of the residual liquid. This mechanism may result in rapid shifts of $\mathrm{S}$ isotope composition of sulfides, from positive to negative $\delta^{34} \mathrm{~S}$ values with great heterogeneity in individual samples (e.g. Mckibben and Eldrige,1990) as those observed in our study. The evidences for boiling conditions in the epithermal deposits at Djibouti have been also supported by the presence of adularia, platy calcite and arsenic indicative of phase separation (Moussa et al., 2012). Phase separation may also play an important control on the precipitation of precious metals in Djibouti, as found elsewhere (Saunders and Schoenly, 1995; Simmons et al., 2005).

\subsection{Strontium isotope systematics: importance of evaporites in ore-forming processes of epithermal deposits}

Altogether, hydrothermal veins and gypsum \pm anhydrite from the different sites yield a range of ${ }^{87} \mathrm{Sr} /{ }^{86} \mathrm{Sr}$ between 0.7038 and 0.7079 . By comparison, ${ }^{87} \mathrm{Sr} /{ }^{86} \mathrm{Sr}$ ratios ranging from 0.7030 and 0.707 have been reported for the rhyolites and basalts of Djibouti (Barrat et al., 1993). Such values reflect heterogeneities in the lavas erupted before the opening of the Gulf of Tadjoura due to significant contamination by continental crust whereas more recent lavas were contaminated by hydrothermally altered mafic crust (Barrat et al., 1993). Hence, according to the ${ }^{87} \mathrm{Sr} /{ }^{86} \mathrm{Sr}$ isotope systematics, three different groups could be identified: 1) ${ }^{87} \mathrm{Sr} /{ }^{86} \mathrm{Sr}$ between 0.7035 and $\sim 0.704$ which characterize the Hes Daba, Asa Leyta, Arta and Arta Plage sites, within the range of igneous rocks values from Djibouti (Barrat et al., 1993); 2) more radiogenic ${ }^{87} \mathrm{Sr} /{ }^{86} \mathrm{Sr}$ values from 0.704 to 0.706 observed in the Hes Daba, Arta and Asa Leyta sites, indicative of significant alteration of the 
underlying volcanic rocks; 3$){ }^{87} \mathrm{Sr} /{ }^{86} \mathrm{Sr}$ ratios (0.7072 to 0.7079$)$ of the mineralized veins from Ali Addé site suggesting an important contribution of seawater-derived sulfate (0.7090).

Hydrothermal activity is ubiquitous in the Djibouti rift system (Moussa et al., 2012) and the intense extensional fault activity greatly favored the circulation of hydrothermal fluids (Fouillac et al., 1989). The Sr isotopic composition in veins and gypsum can be modified by interactions with variably altered rocks and by mixing with different fluids having different isotopic ratios (e.g. Kusakabe et al., 1990; Bach and Humphris, 1999; Paytan et al., 2002; Roberts et al., 2003; Alt and Teagle, 2003). The highest ${ }^{87} \mathrm{Sr} /{ }^{86} \mathrm{Sr}$ values at 0.707 may reflect the contribution of $\mathrm{Sr}$ derived from hydrothermally-altered substrate rocks. Gasse et al. (1986) proposed that the Mablas rhyolites were affected by intense alteration with the deposits of gypsum. If we consider the paleogeographical evolution of the SE Afar rift, most of its southeastern part has been affected by marine infiltration from the Red Sea. In this context, more radiogenic ${ }^{87} \mathrm{Sr} /{ }^{86} \mathrm{Sr}$ values are consistent with precipitation from hydrothermal fluids, although the relative contribution of $\mathrm{Sr}$ derived from altered crust and evaporitic sequences cannot be easily discriminated using $\mathrm{Sr}$ isotope systematics alone. Distinguishing between these two sources is important considering that evaporites play a role in the genesis of a large base metal ore bodies by the provision of anions for complexing metals in solution and by providing the sulfur necessary to precipitate the metals (Kyle, 1991; Warren, 1997; Palmer et al., 2004). In the section below, we applied combined $\mathrm{S}$ and $\mathrm{Sr}$ isotopes to provide further constraints.

\subsection{Combined Sr-S isotope data of sulfate and establishment of genetic model for epithermal}

\section{deposits}

A comparison of $\delta^{34} \mathrm{~S}$ versus ${ }^{87} \mathrm{Sr} /{ }^{86} \mathrm{Sr}$ signatures of gypsum from Asa Leyta and Arta Plage is reported in Figure 4. In each site, elevated (i.e. more radiogenic) ${ }^{87} \mathrm{Sr} /{ }^{86} \mathrm{Sr}$ ratios in gypsum correspond to heavier $\delta^{34} \mathrm{~S}$ values, consistent with the contribution of seawater-derived sulfate. The presences of sulfate minerals with relatively lower ${ }^{87} \mathrm{Sr} /{ }^{86} \mathrm{Sr}$ ratios $(\sim 0.704)$ and $\delta^{34} \mathrm{~S}(\sim 2 \%$ ) are 
consistent with a predominantly volcanic rock-derived source, either resulting from $\mathrm{SO}_{2}$ magmatic contribution or oxidation of hydrothermally-derived $\mathrm{H}_{2} \mathrm{~S}$. In either cases, $\delta^{34} \mathrm{~S}$ and ${ }^{87} \mathrm{Sr} /{ }^{86} \mathrm{Sr}$ values indicate mixing between magmatic/hydrothermal fluid and seawater sulfate.

For Babba Alou, Hes Daba, Arta and Asa Leyta sites, light isotopic composition of sulfur ( $<0 \%$ ) indicate $\mathrm{SO}_{2}$ magma degassing in the deep parts of the hydrothermal system. The ${ }^{87} \mathrm{Sr} /{ }^{86} \mathrm{Sr}$ ratios for Hes Daba, Arta and Asa Leyta sites range between 0.7038 and 0.7064 which is consistent with hydrothermal fluid signatures and suggesting that the magmatic volatiles interacted with igneous rocks. The Ali Addé, Da'asbiyo2, Hes Daba, Babba Alou, Arta and Asa Leyta sites, sulfur and strontium isotopic compositions show $\mathrm{Sr}$ and $\mathrm{S}$ isotope signatures similar to volcanic rocks (Fig. 6). The Arta Plage, Babba Alou and Asa Leyta show both light and variable $\delta^{34}$ S values (-1.5 to $16.3 \%$ ) with more radiogenic strontium isotope ratios (0.7064 for Arta Plage).

Figure 4 shows a compilation of $\delta^{34} \mathrm{~S}$ values of sulfides and sulfates from worldwide epithermal systems, modern seafloor hydrothermal systems and the Djibouti rift. Although sulfide $\delta^{34} \mathrm{~S}$ data from Djibouti overlap with different types of epithermal deposits, they are most similar to epithermal portion of alkalic and low sulfidation deposits.

Based on field and mineralogical observations, Moussa et al. (2012) identified different types of mineralization corresponding to different depths in the Djibouti hydrothermal rift system. Apart from the deepest zone in the hydrothermal system which recorded epidote alteration in the south of Djibouti and the Asal Rift, hydrothermal mineralization were encountered at two different depths 1) deep, with massive quartz veins containing sulfides (Hes Daba, Ali Addé and Arta sites) and brecciated veins (Da'asbiyo, Babba Alou and Asa Leyta); 2) shallow, with evidence of boiling conditions, where chalcedony with adularia and platy calcite are common (Ali Addé, Hes Daba, Arta and Asa Leyta sites). The highest Au concentration occurs in the latter type. Gold is mostly concentrated in banded chalcedony, whereas massive quartz or breccias are less enriched or barren. A third type is represented by sublacustrine hydrothermal precipitates consisting of gypsum mounds (Lake Asal) or stockworks (Babba Alou, Arta Plage and Asa Leyta sites). The $\delta^{34} \mathrm{~S}$ value of gypsum 
corresponds to the Lake Asal site with value of $21.3 \%$. The Lake Asal remains hypersaline with about $300 \mathrm{~g} / \mathrm{L} \mathrm{NaCl}$ which is 8 to 9 times the salinity of seawater (Gasse and Fontes, 1989). In addition, paleoenvironment and paleohydrology studies of the Lake Asal have shown that the latter was periodically affected by the infiltration of marine water (Gasse and Fontes, 1989). Therefore, a $\delta^{34} \mathrm{~S}$ value of $21.3 \%$ for gypsum from the lake obtained in our study is fully consistent with a marine origin (Rees et al., 1978; Paris et al., 2013). Combining sulfur and strontium isotope systematics further allows to identify the source of mineralization in the area. If we consider the different levels of the hydrothermal system in the Djibouti rift (see above), we can suggest that two major types of fluids contributed to the formation of the deposits: 1) hydrothermal fluids enriched in magmatic volatiles leading to significant leaching of the underlying volcanic rocks (e.g. Da'asbiyo2, Ali Addé, Hes Daba, Arta and Babba Alou; 2) hydrothermal fluids, probably initially enriched in magmatic $\mathrm{SO}_{2}$, but that underwent significant dilution with seawater and/or contamination with evaporite layers that dissolved during the circulation of hydrothermal fluid passes (e.g. Babba Alou, Arta Plage and Asa Leyta sites). 


\section{Conclusions}

Sulfur and strontium isotopic analyses of sulfide and sulfate of mineralized veins from the SE Afar rift have been measured to characterize the sources of the mineralizing fluids. Light $\delta^{34} S$ values of pyrite provide evidence for magmatic $\mathrm{SO}_{2}$ contribution while ${ }^{87} \mathrm{Sr} /{ }^{86} \mathrm{Sr}$ of mineralized veins suggests the contribution of variably altered volcanic rock sources. Coupled $\delta^{34} \mathrm{~S}$ and ${ }^{87} \mathrm{Sr} /{ }^{86} \mathrm{Sr}$ values of gypsum suggest variable extent of mixing between seawater-derived sulfate and hydrothermal fluids. The variable $\delta^{34} \mathrm{~S}$ values of pyrite and the presence of platy calcite, adularia, arsenic, suggest possible boiling conditions in some sites (i.e. Ali Addé, Hes Daba, Arta and Asa Leyta).

These results allow us to identify that gold deposits in the region are mainly related to magmatic contribution, allowing to classify the deposits as epithermal gold systems, probably close to low sulfidation end-member. By analogy with modern seafloor epithermal-hydrothermal deposits, the observed alteration (illite, chlorite, adularia and platy calcite) suggests that interaction with seawater or underlying evaporites may have buffered the acidity of the magmatic fluid causing a near neutral $\mathrm{pH}$ alteration assemblages to form. In previous studies, the relationship between low-sulfidation epithermal ore deposits and magmatic volatile contribution was difficult to establish due to the predominance of meteoric waters within hydrothermal fluids. To further constrain the origin of the mineralized fluid in Djibouti, additional analysis of $\mathrm{C}, \mathrm{O}, \mathrm{Pb}$ isotope compositions of mineralization; and quartz microthermometry in veins may be required.

In addition, efficient exploration and interpretation of the origin of hydrothermal fluid in the SE Afar rift require integration of all geochemical (textures, mineralogy), geophysical (threedimensional interpretation) and geological data. 
i

\section{Acknowledgments}

Research leading to this communication was supported by the CERD (Center for Research and Studies of Djibouti) and the SCAC (Service de Coopération et d'Action Culturelle Français). We are warmly grateful to Jalludin Mohamed, A.M Caminiti and J. Rolet for the field trip and scientific discussions. We are grateful to Yoan Germain for his assistance in the clean lab and C. Liorzou for technical assistance. We would like to thank an anonymous reviewer and the handling editor, Prof. F. Pirajno for their very constructive comments that substantially improved the manuscript. 


\section{i}

\section{References}

Alt, J.C., Anderson, T.F., Bonnell, L., 1989. The geochemistry of sulfur in a $1.3 \mathrm{~km}$ section of hydrothermally altered oceanic crust, DSDP Hole 504B. Geochim et Cosmochim Act, 53, 1011-1023.

Aoki, M., 1991 Mineralogical features and genesis of alunite solid solution in high temperature magmatic-hydrothermal systems.Geol Surv Japan Rep 277, 35-37

Arnold, M., Sheppard, S.M.F., 1981. East Pacific Rise at latitude 21 N: isotopic composition and origin of the hydrothermal sulphur. EPSL, 56,148-156.

Alt, Jeffrey C., Damon A.H. Teagle 2003. Hydrothermal alteration of upper oceanic crust formed at a fast-spreading ridge: mineral, chemical, and isotopic evidence from ODP Site 801. Chem Geol 201,191-211.

Arribas, Jr, A. Cunningham, A., Rytuba, C.G., J.J., Rye, R.O., Kelly, W.C., Podwysocki, M.H., 1995. Geology, geochronology, fluid inclusions, and isotope geochemistry of the Rodalquilar gold alunite deposit, Spain. Econ Geol 90, 795.

Arribas Jr. A., 1995. Characteristics of high-sulfidation epithermal deposits, and their relation to magmatic fluid: Mineralogical Association of Canada Short Course Series, v. 23.

Audin L, Quidelleur X, Coulié E, Courtillot V, Gilder S, Manighetti I, Gillot PY, Tapponnier P,\& Kidane T2004. Paleomagnetism and $\mathrm{K}-\mathrm{Ar}$ and $40 \mathrm{Ar} / 39 \mathrm{Ar}$ ages in the Ali Sabieh area (Republic of Djibouti and Ethiopia): constraints on the mechanism of Aden ridge propagation into southeastern Afar during the last 10 Myr. Geophys J Int 158, 327-345

Bach, W.,S. E., Humphris, 1999. Relationship between the $\mathrm{Sr}$ and O isotope compositions of hydrothermal fluids and the spreading and magma-supply rates at oceanic spreading centers. Geol 27, 1067-1070.

Barrat, J. A., Jahn, B. M., Fourcade, S., Joron, J. L., 1993. Magma genesis in an ongoing rifting zone: the Tadjoura Gulf (Afar area). Geochim et Cosmochim Act, 57, 2291-2302.

Barberi, F., Ferrara, G., Santacroce, R. Varet, J., 1975. Structural evolution of the Afar triple junction. Afar Depression of Ethiopia: Stuttgart, Germany, Schweizerbart, Scientific Report, $14,38-54$.

Barberi, F.,Varet, J., 1977. Volcanism of Afar: Small-scale plate tectonics implications. Bulletin of the Geolog Soc of Am, 88, 1251-1266.

Bosch, B., Deschamps, J., Leleu, M., Lopoukhine, M., Marcé, A. Vilbert, C., 1977.The geothermal zoneof Lake Asal (T.F.A.I.).Geochemical and experimental studies. Geothermics, 5,166-175.

Canfield, D.E 2001. Biogeochemistry of Sulfur Isotopes. Reviews in Mineralogy and Geochemistry.43, 607-636.

Chiba, H., Uchiyama, N., \& Teagle, D. A. H., 1998.Stable isotopestudy of anhydrite and sulfide minerals at the TAG hydrothermal mound, Mid-Atlantic Ridge, $26^{\circ} \mathrm{N}$, Proc. Ocean Drill. Program Sci. Rep., 158, 85-90. 
Claypool, G.E., Holser, W.T., Kaplan, I.R., Sakai, H., Zak, I., 1980. The age curves of sulfur and oxygen isotopes in marine sulfate and their mutual interpretation. Chem geol.28, 199-260.

Craddock, P.R., Bach, W., 2010. Insights to magmatic-hydrothermal processes in the Manus backarc basin as recorded by anhydrite. Geochim. Cosmochim. Acta.74, 5514-5536.

Craddock, P. R., Rouxel, O. J., Ball, L. A., Bach, W., 2008. Sulfur isotope measurement of sulfate and sulfide by high-resolution MC-ICP-MS. Chem Geol. 253, 102-113.

Chu, N. C., Henderson, G. M., Belshaw, N. S., Hedges, R. E., 2006. Establishing the potential of Ca isotopes as proxy for consumption of dairy products. Applied geochemistry. 21, 1656-1667.

Cooke, D.R., Simmons, S.F., (2000) Characteristics and genesis of epithermal gold deposits: Rev in Econ Geol, v. 13, p. 221-244.

Daoud, M.A., Le Gall, B., Maury, R., Rolet, J., Huchon, P., Guillou, H., 2011. Young rift kinematics in the Tadjoura rift, western Gulf of Aden Republic of Djibouti, Tectonics, 30, 1, DOI: $10.1029 / 2009$ TC002614.

De Chabalier J.B., Avouac J.P., 1994.Kinematics of the Asal Rift (Djibouti) determined from the deformation of Fieale Volcano. Sc. 265, 1677-1681

Deniel, C., Vidal, P., Coulon, C., Vellutini, P., Piguet, P., 1994.Temporal evolution of mantle sources during continental rifting. The volcanism of Djibouti (Afar). J of Geoph Res: Solid Earth. 99, 2853-2869.

de Ronde, C.E.J., Hannington, M., Stoffers, P., Wright, I., Gennerich, H.H., Browne, P., Herzig, P., 2000. Massive sulfide mineralisation associated with a frontal arc volcano: Brothers hydrothermal system, southern Kermadec arc, New Zealand [abs.]: Hobart, Tasmania, Australia, Centre for Ore Deposit Research Special Publication.3, 37-38.

Drummond, S.E., 1981. Boiling and mixing of hydrothermal fluids: chemical effects on mineral precipitation. Pennsylvania State University.

Elderfield, H., andGreaves, M.J., 1981.Strontium isotope geochemistry of Icelandic geothermal systems and implications for seawater chemistry. Geochim et Cosmochim Act. 45, 22012212.

Einaudi, M., Hedenquist, J., Inan, E., 2003.Sulfidation state of fluids in active and extinct hydrothermal systems: transitions from porphyryto epithermal environments. Soc Econ Geol Spec Publ. 10,285-314

Field, C.W., Fifarek, R.H., 1985.Light stable isotope systematics in epithermal systems: Rev in Econ. Geol. 2, 99-128.

Fontes, J. C., Zuppi, G. M., Florkowski, T., Pouchan, P., 1979.Preliminary isotopic study of Lake Asal system (Republic of Djibouti).In Isotopes in lake studies.

Fouillac, C., Fabriol, R., Iundt, F., 1983.Champ géothermiqued'Asal. Synthèse des données disponibles au ler janvier 1983. Rapport B.R.G.M. 83SGN022GTH, 71 pp. 
Fouillac, A., Fouillac, C., Cesbron, F., Pillard, F., Legendre, O., 1989.Water-rock interaction between basalt and high-salinity fluids in the Asal Rift, Republic of Djibouti.Chem Geol. 76, 271-289

Gadalia, A., 1980. Les Rhyolites du stade initial de l'ouverture d'un rift : Exemple des Rhyolites Miocène de l'Afar. Thesis, University of Orsay.

Gamo, T., Okamura, K., Charlou, J.L., Urabe, T., Auzende, J.M., Ishibashi, J., Shitashima, K., Chiba, H., Binns, R.A., Gena, K., Henry, K., Matsubayashi, O., Moss, R., Nagaya, Y., Naka, J.,Ruellan, E.,1997.Acidic and sulfate-rich hydrothermal fluids from the Manus back-arc basin, Papua New Guinea.Geol. 25, 139-142

Gasse, F., Street J., 1978.Late Quaternary lake-level fluctuations and environments of the northern Rift Valley and Afar region (Ethiopia and Djibouti). Paleogeogr, Paleoclima, Paleoecol. 24, 279-325.

Gasse, F., Fontes, J.C., 1989. Palaeoenvironments and palaeohydrology of a tropical closed lake (L. Asal, Djibouti) since 10000 yrs B.P. Palaeogeogr, Palaeoclimatol, Palaeoecol., 69, 67-102.

Gemmell, J.B., Sharpe, R., Jonasson, I.R., Herzig, P.M., 2004. Sulfur isotope evidence for magmatic contributions to submarine and subaerial gold mineralization: Conical Seamount and the Ladolam gold deposit, Papua New Guinea. Econ Geol. 99, 1711-1725

Gemmell, J.B., Binns, R.A., \& Parr, J.,M., (1999) Submarine, high sulfidation alteration within Desmos caldera, Manus basin, PNG, inC.J. Stanley et al., eds, Mineral deposits: Processes to processing, v.1, Proceedings of the 5th biennial SGA meeting and the 10thh quadrennial IAGOD symposium: London, Balkema, 503-506.

Goldhaber, M. B., Kaplan, I. R.,1980.Mechanisms of sulfur incorporation and isotope fractionation during early diagenesis in sediments of the Gulf of California. Mar Chemi. 9, 95-143.

Grassineau, N.V., 2006. High-Precision EA-IRMS Analysis of S and C Isotopes in Geological Materials. In: Frontiers in Analytical Geochemistry - Appl Geochem. Special Issue. 21, 756765

Grassineau, N.V., Mattey, D.P., Lowry, L., 2001. Rapid sulphur isotopic analyzes of sulphide and sulphate minerals by continuous flow-isotope ratio mass spectrometry (CFIRMS). Anal. Chem. 73, 220-225

Hayba, D.O., Bethke, P.M., Head, P., Folek, N.K., 1985. Geologic, mineralogic and geothermal characteristic of volcanic-hosted epithermal precious metal deposits.In Geology and geochemistry of Epithermal Systems. (B.R. Berger and P.M. Betke, eds. 7) Reviews Economic Geology. 2, 129-167

Hedenquist, J.W., Arribas, A., Gonzalez-Urien E.,2000. Exploration for epithermal gold deposits. Rev Econ Geol. 13,245-277

Henley, R. W.; Ellis, A. J.1983. Geothermal systems ancient and modern: a geochemical review. Earth Science Reviews.19, 1-50. 
Henley, R. W., Berger, B. R., 2011. Magmatic-vapor expansion and the formation of highsulfidation gold deposits: chemical controls on alteration and mineralization. Ore Geol Rev. 39, 63-74.

Herzig, P., Hannington, M. \&Arribas Jr, A., (1998a) Sulfur isotopic composition of hydrothermal precipitates from the Lau back-arc: implications for magmatic contributions to seafloor hydrothermal systems. Mineralium Deposita, 33(3): 226-237.

Herzig, P. Hannington, M., Stoffers, P., Shipboard, \&Party., (1998b)Petrology, gold mineralization and biological communities at shallow submarine volcanoes of the New Ireland fore-arc (Papua New Guinea): preliminary results of R/V Sonne cruise SO-133. Inter Ridge News, 7: 34-38.

Holland, H.D., 1965. Some applications of thermochemical data to problems of ore deposits;[Part] 2, Mineral assemblages and the composition of ore forming fluids. Econ Geol. 60, 11011166 .

Kim, J., Lee, I., Halbach, P., Lee, K. Y., Ko, Y. T., Kim, K. H., 2006 Formation of hydrothermal vents in the North Fiji Basin: Sulfur and lead isotope constraints. Chem Geol. 233, 257-275.

Kim, J., Lee, I., Lee, K. Y.,2004. S, Sr, and Pb isotopic systematics of hydrothermal chimney precipitates from the Eastern Manus Basin, western Pacific: evaluation of magmatic contribution to hydrothermal system. Journal of Geophysical Research: Solid Earth (19782012), 109 (B12).

Kusakabe, M., Mayeda, S., Nakamura, E., 1990.S, O and Sr isotope systematics of active vent materials from the Mariana backarc basin spreading axis at $18 \mathrm{~N}$. Earth and Planetary Science Letters. 100, 275-282.

Kyle, J.R., (1991) Evaporites, evaporitic processes and mineral resources. In: Melvin, J.L. (Ed.), Evaporites, Petroleum and Mineral Resources. Elsevier, Netherlands, pp. 477- 533.

Labidi, J., Cartigny, P., Moreira. M., 2013. Non-chondritic sulphur isotope composition of the terrestrial mantle. Nature. 501, 208-211.

Le Gall, B.., Daoud, M.A., Maury, R.C., Rolet, J., Guillou, H., Sue, C., 2010.Magma-driven antiform structures in the Afar rift: the Ali Sabieh range, Djibouti. J. Struct. Geol., 32,843854

Jensen, M.L. (1967) Sulfur isotopes and mineral genesis. Geochemistry of hydrothermal ore deposits: New York, Holt, Rinehart and Winston. 143-165.

Manighetti, I., Tapponnier P., Courtillot V., Gruszow S., 1997. Propagation of rifting along the Arabia-Somalia plate boundary: The Gulfs of Aden and Tadjoura. Jour of Geophy Research.102, 2681-2710.

McKibben, M. A., C. S. Eldridge 1990. Radical sulfur isotope zonation of pyrite accompanying boiling and epithermal gold deposition: A SHRIMP study of the Valles Caldera, New Mexico, Economic Geology, 85, 1917-1925. 
Mills, R.A., Teagle, D.A.H.,Tivey, M.K., 1998.Fluid mixing and anhydrite precipitation within the TAG mound.In: Herzig, P.M., Humphris, S.E., Miller, D.J., Zierenberg, R.A. (Eds.), Proc. Ocean Drill. Program, Sci. Results.158, 119- 127.College Station, TX.

Mills, R.A., Tivey, M.K., 1999.Sea water entrainment and fluid evolution within the TAG hydrothermal mound: evidence from analyses of anhydrite. In: Cann, J.R., Elderfield, H., Laughton, A. (Eds.), Mid-Ocean Ridges. The Royal Society, Cambridge, pp. 225- 263.

Moussa, N., Fouquet, Y., Le Gall, B., Caminiti, A. M., Rolet, J., Bohn, M., Jalludin, M., 2012.First evidence of epithermal gold occurrences in the SE Afar Rift, Republic of Djibouti. Miner Deposita, 47, 563-576.

Naden, J., Kilias, S. P., Darbyshire, D. F., 2005.Active geothermal systems with entrained seawater as modern analogs for transitional volcanic-hosted massive sulfide and continental magmatohydrothermal mineralization: The example of Milos Island, Greece. Geol. 33, 541-544.

Ohmoto, H.,Rye, R.O., 1979.Isotopes of sulfur and carbon. In: Barnes, H.L. (Ed.), Geochemistry of Hydrothermal Ore Deposits, 2nd ed. Wiley, New York. 509- 567.

Ono, S., Shanks WC., Rouxel, O.J., Rumble, D., 2007. S-33 constraints on the seawater sulfate contribution in modern seafloor hydrothermal vent sulfides. Geochim. et Cosmochim. Acta, $71,1170-1182$.

Palmer, M. R., Helvací, C., Fallick, A. E., 2004. Sulphur, sulphate oxygen and strontium isotope composition of Cenozoic Turkish evaporites. Chem. Geol., 209, 341-356.

Paris, G., Sessions, A. L., Subhas, A. V., Adkins, J. F., 2013. MC-ICP-MS measurement of $\delta 34$ S and $\Delta 33 \mathrm{~S}$ in small amounts of dissolved sulfate. Chem. Geol., 345, 50-61.

Paytan, A., Mearon, S., Cobb, K., Kastner, M., 2002. Origin of marine barite deposits: Sr and S isotope characterization. Geol. 30, 747-750.

Paytan, A., Kastner, M., Campbell, D., Thiemens, M. H., 1998. Sulfur isotopic composition of Cenozoic seawater sulfate. Sci. 282, 1459-1462.

Polliand, M., Moritz, R., 1999. Basement-hosted quartz barite sulfide veins in the French Alps: A record of alpine tectonic fluid expulsion in the external crystalline massifs-structural, fluid inclusion, and isotope ( $\mathrm{S}$ and $\mathrm{Sr}$ ) evidences. Econ Geol. 94, 37-56.

Pinzutti, P., Humler, E., Manighetti, I., Gaudemer, Y. 2013. Petrological constraints on melt generation beneath the Asal rift, Djibouti using Quaternary basalts. Geochemistry, Geophysics, Geosystems, 14, 2932-2953.

Rainbow, A., Clark, A.H., Kyser, T.K., Gaboury, F., Hodgson, C.J., 2005. The Pierina epithermal $\mathrm{Au}-\mathrm{Ag}$ deposit, Ancash, Peru: paragenetic relationships, alunite textures, and stable-isotope geochemistry. Chem. Geol., 215, 235-252.

Rees, C., Jenkins, W., Monster, J., 1978. The sulphur isotopic composition of ocean water sulphate. Geochim. et Cosmochim. Acta, 42, 377-381. 
Reeves, E., 2010. Laboratory and field-based investigations of subsurface geochemical processes in seafloor hydrothermal systems.Diss. Massachusetts Institute of Technology.

Richards, J., (1995). Alkalic-type epithermal gold deposits - a review: Mineralogical Association of Canada Short Course Series, v. 23.

Roberts, S., Bach, W., Binns, R. A., Vanko, D. A., Yeats, C. J., Teagle, D. A. H.,McDonald, B. 2003. Contrasting evolution of hydrothermal fluids in the PACMANUS system, Manus Basin: the Sr and S isotope evidence. Geol. 31, 805-808.

Robineau, B., 1979. La zone d'Arta et le Rift d'Asal-Ghoubbet: leur étude intégrée dans le contexte géodynamique de l'Afar. Thesis. Université des Sciences et Techniques du Languedoc. Montpellier

Rouxel, O., Fouquet, Y., Ludden, J.N., 2004. Subsurface processes at the Lucky Strike hydrothermal field, Mid-Atlantic ridge: evidence from sulfur, selenium, and iron isotopes 1. Geochem. et Cosmoch. Acta, 68, 2295-2311.

Rye, R.O., Bethke, P.M., Wasserman, M.D., 1992.The stable isotope geochemistry of acid sulfate alteration. Econ Geol. 87, 225-262.

Rye, R.O., 2005. A review of the stable-isotope geochemistry of sulfate minerals inselected igneous environments and related hydrothermal systems. Chemi Geol 215, 5-36.

Sakai, H., Marais, D., Ueda, A., Moore, J., 1984. Concentrations and isotope ratios of carbon, nitrogen and sulfur in ocean-floor basalts. Geochim et Cosmochim Acta, 48, 2433-2441.

Saunders, J. A.,Schoenly, P. A., 1995. Boiling, colloid nucleation and aggregation, and the genesis of bonanza Au-Ag ores of the Sleeper deposit, Nevada. Miner. Deposita. 30, 199-210.

Seal, R. R.,2006. Sulfur isotope geochemistry of sulfide minerals. Rev. in Miner. and Geochem. 61, 633-677.

Shanks, III, W.C.,2001. Stable isotopes in seafloor hydrothermal systems: vent fluids, hydrothermal deposits, hydrothermal alteration and microbial process. Rev. Mineral.Geochem. 43, 469525.

Shanks III, W., Böhlke, J., Seal, I. R.R., 1995. Stable Isotopes in Mid-Ocean Ridge Hydrothermal Systems: Interactions between Fluids, Minerals, and Organisms. Seafloor Hydrothermal Systems: Physical, Chemical, Biological, and Geological Interactions: American Geophysical Union, Geophysical Monograph Series.91, 194-221.

Shanks III, W., Bischoff, J.L., Rosenbauer, R.J., 1981. Seawater sulfate reduction and sulfur isotope fractionation in basaltic systems: Interaction of seawater with fayalite and magnetite at 200$350^{\circ}$ C. Geochim et Cosmoch Acta, 45, 1977-1995.

Shen Y., Buick R., Canfield, D.E., 2000.Isotopic evidence for microbial sulphate reduction in the early Archaean era. Nature. 410, 77-81

Shikazono, N., Holland, H.D., Quirk, R.F., 1983. Anhydrite in Kuroko deposits: mode of occurrence and depositional mechanisms. Econ. Geol. Monogr. 5, 329-344. 
Schoen, R., White, D.E., Hemley, J.J., 1974. Argillization by descending acid at Steamboat Springs, Nevada: Clays and Clay Minerals, 22, 1-22.

Simmons, S. F. 1995. Magmatic contributions to low-sulfidation epithermal deposits. Magmas, Fluids and Ore Deposits: Ontario, Mineralogical Association of Canada, Short Course Series, 23, 455-477.

Simmons, S.F., Browne, P.R.L., 2000. Hydrothermal minerals and precious metals in the Broadlands-Ohaaki geothermal system: implications for understanding low sulfidation epithermal environments. Econ. Geol. 95, 971-999.

Simmons, S. F., White, N. C., John, D. A., 2005. Geological characteristics of epithermal precious and base metal deposits. Econ. Geol $100^{\text {th }}$ anniversary volume, 29, 485-522.

Sillitoe, R. H., \& Hedenquist, J. W. 2003. Linkages between volcano tectonic settings, ore-fluid compositions, and epithermal precious metal deposits. Special Publication - Society of Economic Geologists, 10, 315-343.

Stietljes, L., 1973. L'axe tectono-volcanique d'Asal (Afar central- Territoire français des Afars et des Issas). Thesis, Université de Paris-Sud, Orsay

Symonds, R.B., Gerlach, T.M., Reed, M.H., 2001. Magmatic gas scrubbing: implications for volcanic monitoring. J. Volcanol. Geotherm. Res., vol. 108. Giggenbach Memorial. 303341.

Teagle, D.A.H., Alt, J.C., Chiba, H., Humphris, S.E., Halliday, A.N., 1998.Strontium and oxygen isotopic constraints on fluidmixing, alteration and mineralization in the TAG hydrothermal deposit. Chem. Geol. 149, $1-24$.

Thode, H., Monster, J., Dunford, H., 1961. Sulphur isotope geochemistry. Geochim. Cosmochim. Acta. 25, 159-174.

Vellutini, P., Piguet, P., 1994. Djibouti-Itinéraires géologiques. Ministère Français de Coopération et d'Action Culturelle à Djibouti. BCIMR et P.FA Ed, p 289

Warren, J.K., 1997. Evaporites, brines and base metals: fluids, flow and 'the evaporite that was'. Aust. J. Earth Sci. 44, 144-183.

White, N. C., Hedenquist, J. W. 1990. Epithermal environments and styles of mineralization: variations and their causes, and guidelines for exploration. $\mathrm{J}$ of Geochem Expl, 36, 445-474.

Zierenberg, R. A., 1994.48 Data Report: Sulfur content of Sediment and Sulfur Isotope values of Sulfide and Sulfate minerals from Middle Valley 1. 


\section{Figure Captions}

Fig.1: Schematical geological map of the Republic of Djibouti (SE Afar Triangle) after Piguet and Vellutini (1994). Yellow stars (and corresponding numbers) are the hydrothermal sites studied in this work. 1 = Da'asbiyo 2; 2 = Ali Addé; $3=$ Arta Plage; $4=$ Arta; 5 = Babba Alou; $6=$ Hes Daba; $7=$ Asa Leyta; 8 = Asal. In the inset: schematic map of the Afar Depression with the location of Djibouti (black rectangle) and the dashed red lines = Red Sea and Gulf of Aden spreading centers.

Fig.2: A- Photograph of the Lake Asal located in the Asal active rift system. The red arrow indicates location of the studied gypsum from Lake Asal. B- Layers of gypsum (Gy) from the Asa Leyta hydrothermally altered site. C- Example of analyzed veins containing pyrite (black layer) from Ali Addé site. D - E- Reflected light microphotograph of pyrite (Py) from the Arta (D) and Ali Addé (E) sites. The gangue mineral is quartz (Q). F- Banded chalcedony veins (Arta). G- Breccia like veins enriched in sulfides (Hes Daba). H- Stockwork of gypsum veins hosted by felsic volcanic material.

Fig 3: Paragenetic sequence of the studied sites.

Fig. 4: $\delta^{34} \mathrm{~S} v \cdot{ }^{87} \mathrm{Sr} /{ }^{86} \mathrm{Sr}$ diagram for sulfate minerals from this study (Arta and Asa Leyta = black squares). The blue squares correspond to anhydrites from hydrothermal chimneys from the Pacmanus hydrothermal site (Kim et al., 2004) and the red square - basalts from Djibouti (data from Barra et al., 1993). The green triangle corresponds to seawater sulfur and strontium isotopic composition (Barra et al., 1993).

Fig. 5: Values of $\delta^{34} \mathrm{~S}(\%, \mathrm{CDT})$ for sulfides and sulfates of epithermal (i) high-sulfidation (Arribas, 1995), (ii) low-sulfidation (Field and Fifarek, 1985), and (iii) modern systems (Gemmell et al. 2004), compared to $\delta^{34} S$ values of sulfide and sulfate minerals from Djibouti.

Fig. 6: Schematic representation of the model proposed. The numbers correspond to (1) Da'asbiyo2, Ali Addé, Hes Daba, Arta, Asa Leyta and Babba Alou; (2) Arta Plage, Babba Alou and Asa Leyta and (3) Lake Asal. 


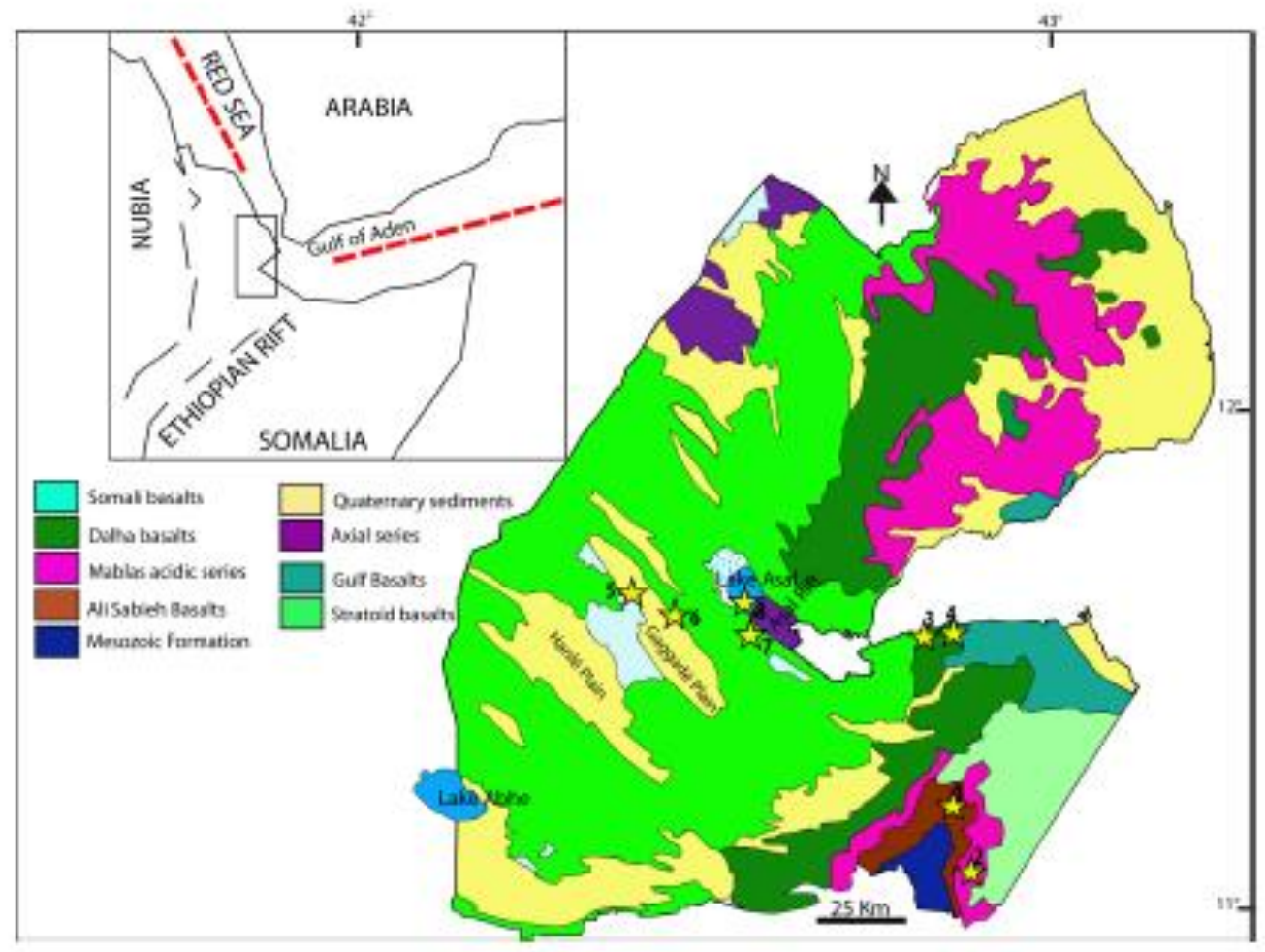

Fig. 1: 

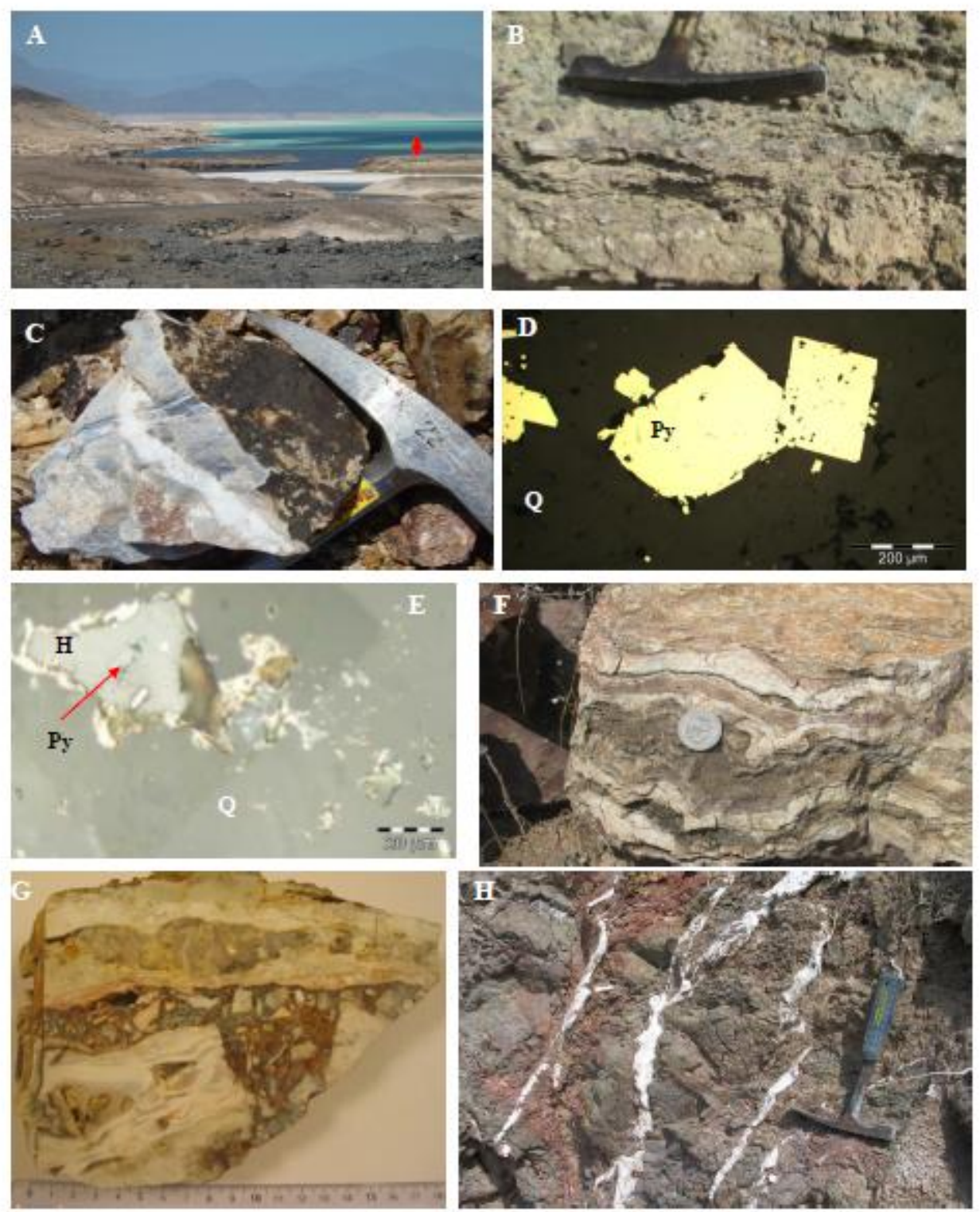

Fig. 2 : 


\begin{tabular}{|c|c|c|c|c|c|c|c|c|}
\hline Minerals Sites & $\begin{array}{l}\text { Asal } \\
<1 \mathrm{Mal}\end{array}$ & $\mid \begin{array}{c}\text { Asa Leyta } \\
\langle<3 \mathrm{Ma}|\end{array}$ & $\begin{array}{l}\text { Hes Daba } \\
\text { (<3.3 Mas) }\end{array}$ & $\begin{array}{c}\text { Babba Alou } \\
(<33 \mathrm{Ma})\end{array}$ & $\begin{array}{c}\text { Arta Plage } \\
(\leqslant 4 \mathrm{Ma})\end{array}$ & Arta & $\begin{array}{l}\text { Ali Addé } \\
(15 \text { to 11Ma: }\end{array}$ & $\begin{array}{l}\text { Pa'asbiyo2 } \\
\text { (15 to 11Ma) }\end{array}$ \\
\hline Chakwopitibe Cifes2 & & & + & & & & + & \\
\hline Bythose Fes & & + & + & & & & + & \\
\hline Pynte FeS2 & & + & + & + & & + & + & + \\
\hline Sphaterive $(Z n$ fe]s & & & + & & & & + & \\
\hline Galens Pb5 & & & + & & & & + & \\
\hline Gold Ave & & & t & & & + & & \\
\hline Eectrum AuA & & & + & & & + & & \\
\hline Argentite Ags & & & + & & & + & & \\
\hline Petzite Ag3AuTe & & & + & & & & & \\
\hline Hessine AgzTe & & & + & & & + & & \\
\hline Teteactpmite BCTO2S & & & & & & & + & \\
\hline Magnetie Fe304 & & & & & & + & & \\
\hline Hemuste Fe203 & & & + & & & + & + & \\
\hline Chalcocke Ci2s & & & & & & & + & \\
\hline Covelibe CuS & & & + & & & & + & \\
\hline Digenite Cu9 55 & & & + & & & & + & \\
\hline Native Sive Ag & & & + & & & & & \\
\hline Nathe Copper Cu & & & + & & & & & \\
\hline Goethite FeOIOH0 & & + & + & + & & + & + & + \\
\hline Bonsile Cus fo 54 & & & + & & & & & \\
\hline Mancasile Fe52 & & & + & & & & + & \\
\hline Adularis KAISI3CO & & + & + & & & + & + & \\
\hline Mnsve Cuartz 5iO2 & & + & + & + & $t$ & + & + & $t$ \\
\hline Chalcodeny $\mathrm{SiO2} 2$ & & + & + & & & + & + & \\
\hline Catbonstes $\mathrm{CHCO}_{3}$ & & + & + & & + & + & + & \\
\hline Gypsum CaSO4 21H2O) & + & + & & + & + & & & \\
\hline
\end{tabular}

Fig 3: 


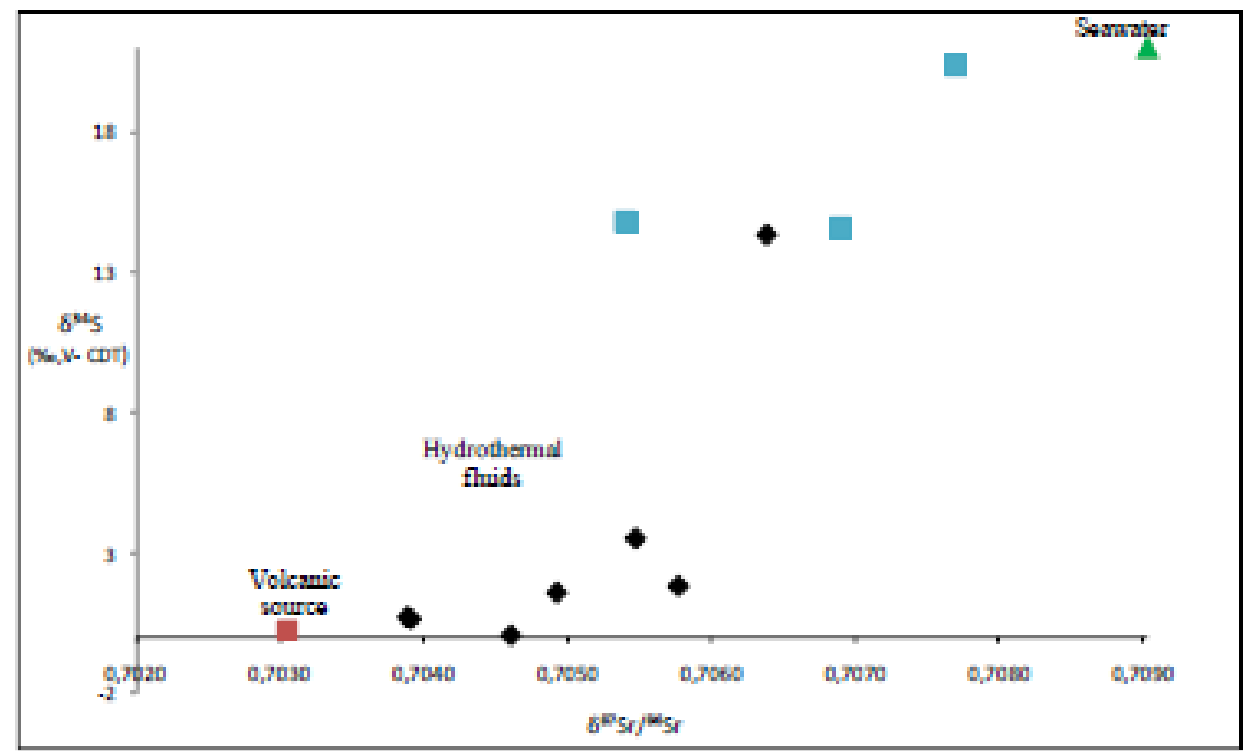

Fig. 4: 


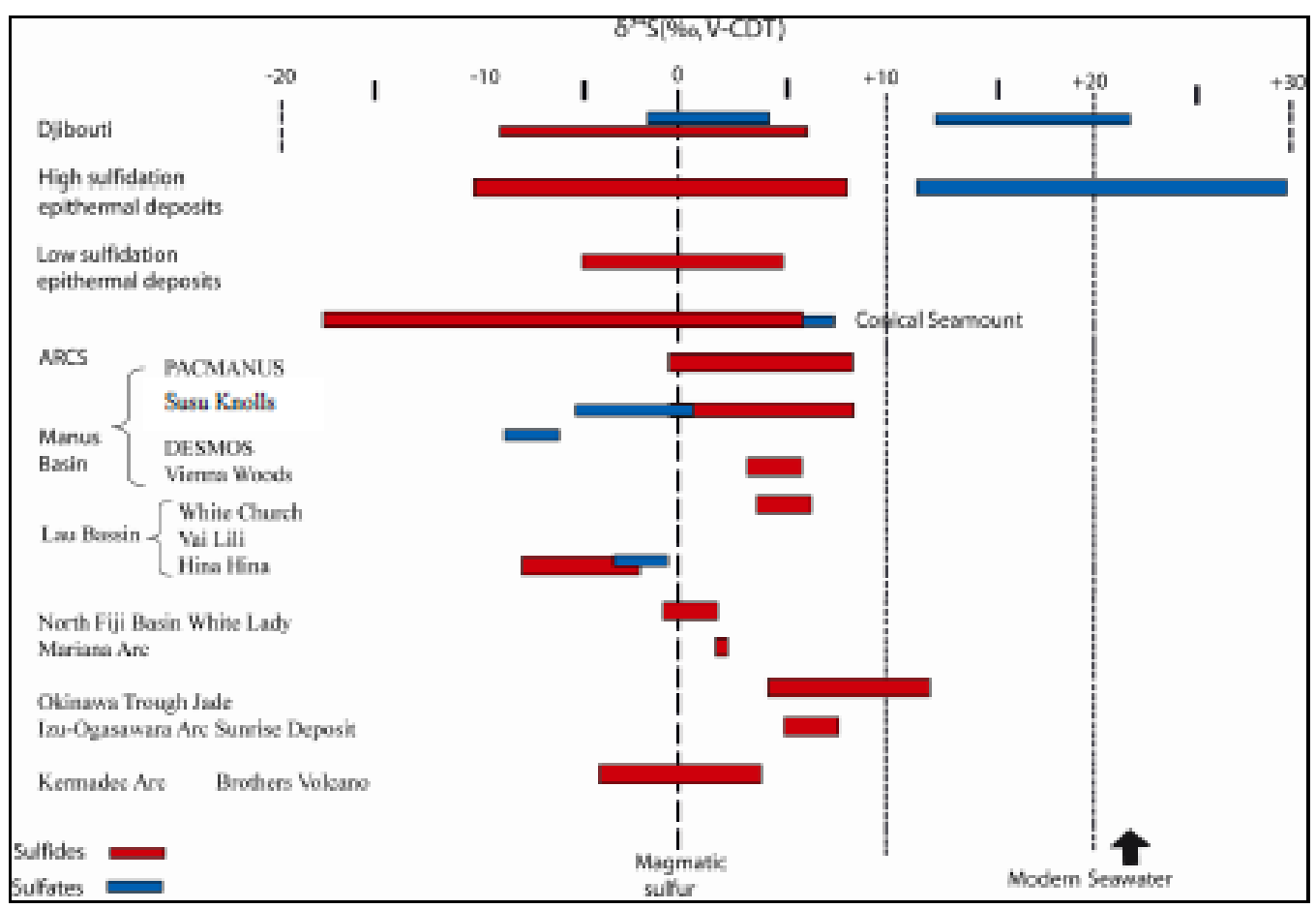

Fig. 5: 


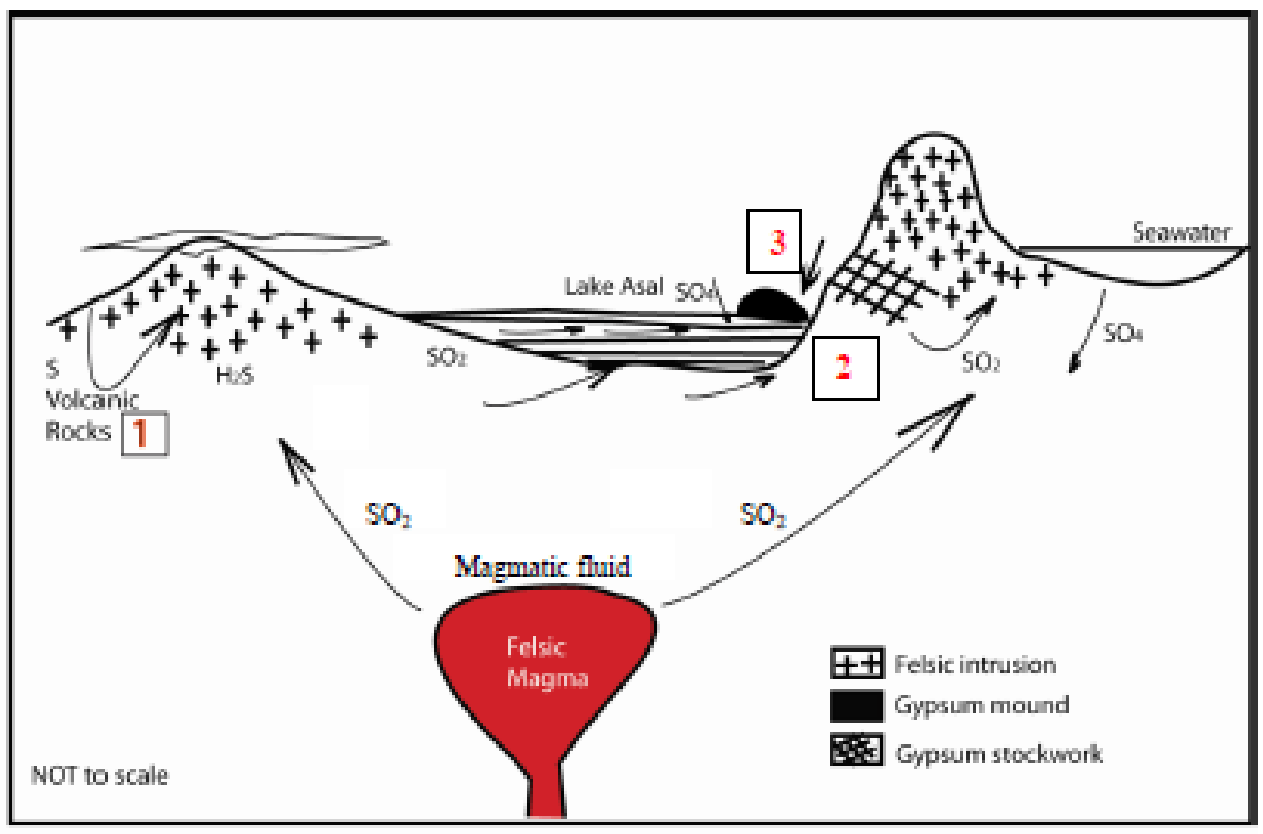

Fig. 6: 


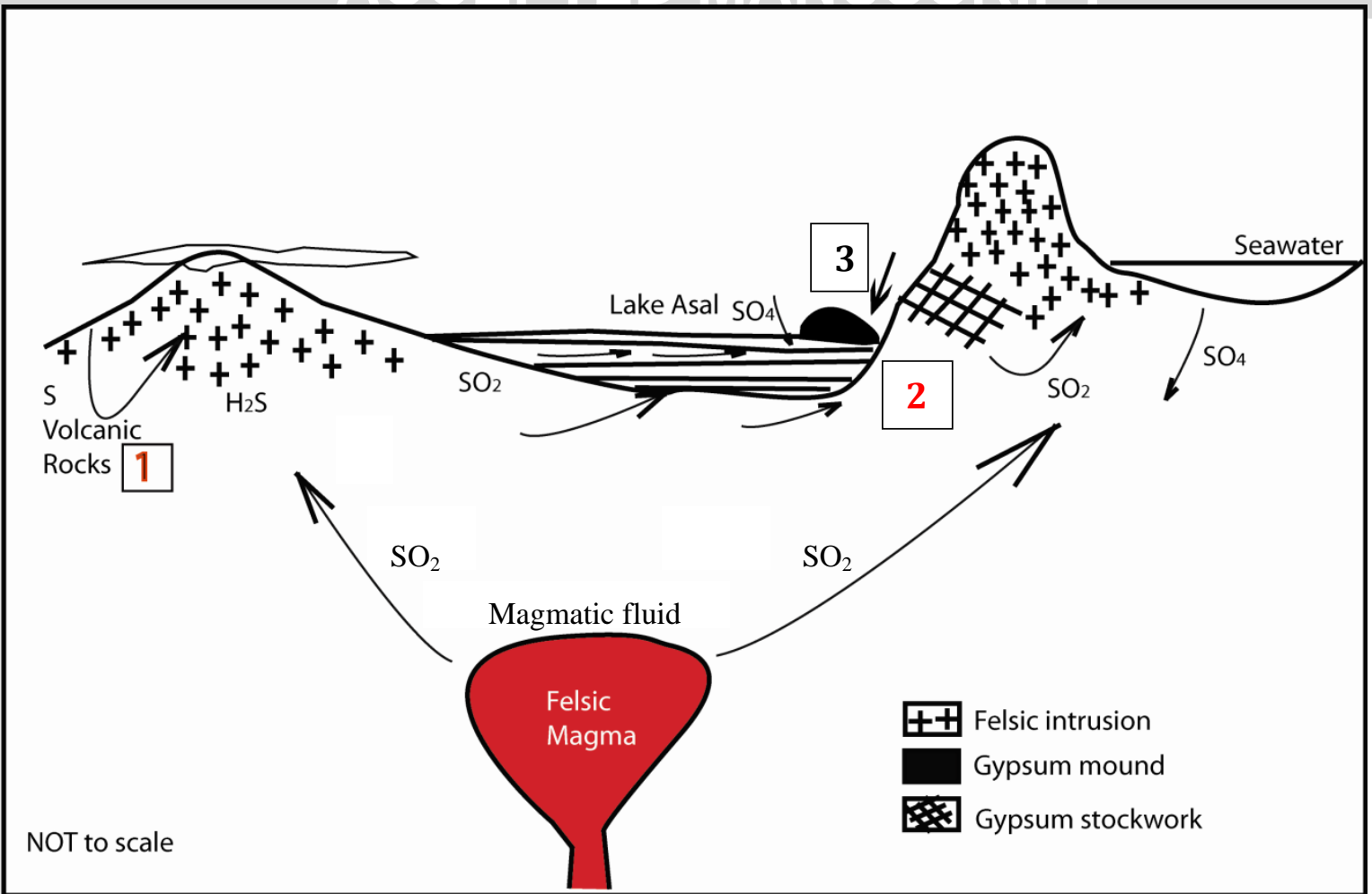

Graphical Abstract

Schematic representation of the model proposed. The numbers correspond to (1) Da'asbiyo2, Ali Addé, Hes Daba, Arta, Asa Leyta and Babba Alou; (2) Arta Plage, Babba Alou and Asa Leyta and (3) Lake Asal. 


\begin{tabular}{|c|c|c|c|c|c|c|}
\hline Sites & Samples & $\delta^{34} \mathrm{~S} v-\mathrm{cdt}^{\mathrm{a}}$ & $\delta^{34} \mathrm{~S} \mathrm{v-cdt}{ }^{b}$ & $\delta^{34} \mathrm{~S} v-\mathrm{cdt}^{\mathrm{c}}$ & ${ }^{77} \mathrm{Sr} /{ }^{86} \mathrm{Sr}$ & $\delta^{34} \mathrm{~S} \mathrm{v-cdt}{ }^{\mathrm{d}}$ \\
\hline \multirow[t]{2}{*}{ Da'asbiyo } & DJ0207 & & & & & 1.5 \\
\hline & & 5.3 & 4.6 & - & & 5.9 \\
\hline \multirow[t]{3}{*}{ Ali Addé } & DJ3807 & - & 4.8 & - & & \\
\hline & & - & 4.6 & - & & \\
\hline & DJ1309 & 3.6 & - & - & & \\
\hline & & - & -1.3 & - & & \\
\hline \multirow[t]{7}{*}{ Babba Alou } & DJ $24-07 C$ & -0.1 & -2.9 & - & & -1.2 \\
\hline & & - & -2.3 & - & & \\
\hline & DJ2407B (Gy) & & & & & -0.2 \\
\hline & DJ2407A (Gy) & & & & & -1.5 \\
\hline & & & & & & 1.0 \\
\hline & AA-02 & & & & & \\
\hline & & 0.3 & - & & & \\
\hline \multirow[t]{7}{*}{ Arta } & DJ0507 & - & 0.3 & & & \\
\hline & & 1.7 & -1.6 & & & \\
\hline & & - & -1.3 & & & \\
\hline & DJ1207b & - & 2.1 & & & -0.3 \\
\hline & & - & -1.5 & & & \\
\hline & & - & -2.1 & & & \\
\hline & A- -05 & 6.6 & - & - & & -0.4 \\
\hline \multirow[t]{15}{*}{ Hes Daba } & & - & 1.4 & - & & \\
\hline & DJ-69 08 & - & 1.6 & - & & \\
\hline & & - & $\begin{array}{l}1.3 \\
2.9\end{array}$ & $\begin{array}{l}- \\
-\end{array}$ & & \\
\hline & & -0.7 & 0.3 & - & & -9.2 \\
\hline & HD 0207 & & ? & - & & \\
\hline & & & 0.6 & - & & \\
\hline & & -0.1 & -1.8 & - & & 1.4 \\
\hline & DJ3407a & & 4.2 & - & & \\
\hline & & & 2.8 & - & & \\
\hline & DJ1009B & 5.2 & - & - & & \\
\hline & Reef1 & 1.2 & - & - & & \\
\hline & Reef3BF3H & 2.1 & - & - & & \\
\hline & Reef3H & 1.3 & - & - & & \\
\hline & Reef3M & 0.5 & & - & & \\
\hline & DJ1R1B & & & & & 1.2 \\
\hline \multirow[t]{15}{*}{ Asa Leyta } & & - & 0.7 & - & & \\
\hline & DJ 70-08 & - & 0.6 & - & & \\
\hline & & - & 1.2 & - & & \\
\hline & & - & -1.5 & - & & \\
\hline & DJ 7608 & - & -0.4 & - & & \\
\hline & & & -0.4 & - & & \\
\hline & & 4.2 & -6.4 & - & & \\
\hline & DJ0207 & - & 1.8 & - & & \\
\hline & & & -4.4 & - & & \\
\hline & DJ8108 & -0.1 & - & - & & \\
\hline & $\mathrm{AL}$ & -0.1 & - & - & & \\
\hline & DJ $0507 \mathrm{~B}$ & 3.7 & - & - & & -1.2 \\
\hline & AL 02 & -0.6 & - & - & & -0.6 \\
\hline & S Lacq* & 16.7 & - & - & & \\
\hline & DJ0707 (Gy) & & & & & 1.9 \\
\hline
\end{tabular}

Arta Plage

DJ-09-09 (Gy)

DJ-74-08 (Gy)

AGD (Gy)

DJ4709-A1 (Gy)

$\begin{array}{ll}-0.8 & 0,70451 \\ 0.7 & 0,70492 \\ 0.1 & 0,70460 \\ 1.6 & 0,70391\end{array}$




$\begin{array}{lllcc}\text { DJ73-08-A (Gy) } & - & - & 3.5 & 0,70547 \\ \text { DJ-01-09-A (Gy) } & - & - & 14.3 & 0,70638 \\ \text { DJ75-08-A (Gy) } & - & - & 1.8 & 0,70577 \\ \text { DJ4709-A (Gy) } & - & - & 0.6 & 0,70389 \\ \text { NBS 123 } & - & - & 17.47 & \\ \text { DJ2807 (Gy) } & & & & 16.3 \\ \text { DJ2707 (Gy) } & & & & 3.1 \\ \text { DJ2607 (Gy) } & & & & \end{array}$

Lac Asal DJ0107 (Gy)

21.3

Tab. 1: Sulfur isotopic compositions of pyrite (Py) and gypsum (Gy) and $\mathrm{Sr}$ isotopic composition of gypsum. * Sulfur from the Lacq (internal standard). Analyses by MC ICPMS (a-bulk powder with $2 s=0.29$; $c$ with $2 s=0.16$ ), Laser methods ( $b$ - pyrite in polished section with $2 s=0.25$ ) and EA-IRMS (d- pyrite) methods. 


\begin{tabular}{|c|c|c|c|c|c|}
\hline Sites & Samples & $\begin{array}{c}\text { Sulfide } \\
\text { Mineralogy }\end{array}$ & Gangue Minerals & $\begin{array}{c}\text { Types of } \\
\text { Hydrothermal } \\
\text { deposits }\end{array}$ & ${ }^{87} \mathrm{Sr} /{ }^{86} \mathrm{Sr}$ \\
\hline \multirow[t]{12}{*}{ Arta } & DJ1207-A-2 & Py, Go, IO & $\mathrm{Q}$ & Breccia & 0,704364 \\
\hline & DJ8508F40H & Py, Au, Go, IO & $\mathrm{Q}$ & Banded Chl & 0,706446 \\
\hline & & $\mathrm{Py}, \mathrm{Au}, \mathrm{Ad}, \mathrm{Go}$, & $\mathrm{Q}$ & Banded Chl & \\
\hline & F2BN140ARTA & IO & & & 0,704205 \\
\hline & DJ8708A & Py, Ad, Go & $\mathrm{Q}$ & Banded Chl & 0,704477 \\
\hline & DJ12BRUB* & - & - & - & 0,704316 \\
\hline & DJ1210A1 & Py, Go & Q & Breccia & 0,704442 \\
\hline & DJ1410B & Py, Go & Q & Breccia & 0,704951 \\
\hline & DJ1610-RM* & - & & - & 0,704524 \\
\hline & DJ1810* & - & & - & 0,704877 \\
\hline & DJ1210B1 & Py, Go & & Breccia & 0,704709 \\
\hline & DJ4809* & . & & - & 0,703543 \\
\hline \multirow[t]{2}{*}{ Arta Plage } & DJ2607E & Gy & Gy & Gypsum & 0,704067 \\
\hline & DJ2907B & $\mathrm{Hm}$ & Q & Breccia & 0,704682 \\
\hline \multirow{6}{*}{ Hes Daba } & & $\begin{array}{c}\text { Cpy, Py, Cu, Bn, } \\
\text { ZnS, Ga, Dgn, }\end{array}$ & & & \\
\hline & DJ3407 & $\mathrm{CuS}, \mathrm{Cv}$ & Q & Breccia & 0,704600 \\
\hline & F1N02C & $\mathrm{Au}, \mathrm{Py}, \mathrm{Ag}$ & $\mathrm{Q}$ & Banded Chl & 0,703918 \\
\hline & DJ1009A & Py, Go & $\mathrm{Q}$ & Breccia & 0,704736 \\
\hline & DJ1009D & Py, Go & $\mathrm{Q}, \mathrm{Ca}$ & Breccia & 0,704125 \\
\hline & DJ4808A* & & - & - & 0,703937 \\
\hline \multirow[t]{5}{*}{ Asa Leyta } & DJ7708 & Py & $\mathrm{Q}$ & Breccia & 0,705120 \\
\hline & DJ2308 & Py, Go & Q & Banded Chl & 0,706124 \\
\hline & DJ0809 & Gy & Gy & Breccia & 0,703884 \\
\hline & DJ7608A & Py & $\mathrm{Q}$ & Breccia & 0,704458 \\
\hline & DJ2110 & Py,Go & Q & Banded Chl & 0,704359 \\
\hline \multirow{4}{*}{ Ali Addé } & & $\begin{array}{c}\text { Cpy, Py, Au, Bn, } \\
\text { ZnS, Ga, Cc, }\end{array}$ & Q & Breccia & \multirow{4}{*}{0,707204} \\
\hline & DJ3807 & Dgn, $\mathrm{CuS}$ & & & \\
\hline & & $\begin{array}{l}\text { Cpy, Py, } \mathrm{Po}, \mathrm{Au}, \\
\mathrm{Sp}, \mathrm{Bn}, \mathrm{Cy}, \mathrm{Cc}\end{array}$ & Q & $\begin{array}{l}\text { Breccia } \\
\text { Breccia }\end{array}$ & \\
\hline & DJ1309 & $\begin{array}{l}\text { Dgn, } \mathrm{Hs}, \mathrm{Ttd} \\
\mathrm{Mg}, \mathrm{Cu}\end{array}$ & & & \\
\hline
\end{tabular}

Tab.2: Strontium isotope ratios of mineralized vein samples and rocks (*). Cpy chalcopyrite, Py pyrite, Hs hessite, Po pyrrhotite Ca calcite, Cc chalcocite, Elt electrum, Ep epidote, Ga galena, Au gold, Bn bornite, Dg digenite, Go goethite, Gy gypsum, Hm hematite, Sp sphalerite, Mg magnetite, IO iron oxides, Ttd tetradymite, Q quartz, Mc marcasite. Native $\mathrm{Cu}$ and native Ag. Chl Chalcedony 